Elisabeth França'

Renato Teixeira"

Lenice Ishitani"I

Bruce Bartholow Duncan ${ }^{\text {IV }}$

Juan José Cortez-Escalante ${ }^{v}$

Otaliba Libânio de Morais Neto ${ }^{\mathrm{VI}}$

Célia Landman Szwarcwald ${ }^{\mathrm{VII}}$

Programa de Pós-Graduação em Saúde Pública. Faculdade de Medicina. Universidade Federal de Minas Gerais. Belo Horizonte, MG, Brasil

Grupo de Pesquisa e Avaliação em Saúde Faculdade de Medicina. Universidade Federal de Minas Gerais. Belo Horizonte, MG, Brasil

III Gerência de Epidemiologia e Informação. Secretaria Municipal de Saúde de Belo Horizonte. Belo Horizonte, MG, Brasil

Programa de Pós-Graduação em Epidemiologia. Faculdade de Medicina. Universidade Federal do Rio Grande do Sul. Porto Alegre, RS, Brasil

Coordenação Geral de Informações e Análise Epidemiológica. Secretaria de Vigilância à Saúde. Ministério da Saúde. Brasília, DF, Brasil.

Instituto de Patologia Tropical e Saúde Pública. Universidade Federal de Goiás. Goiânia, GO, Brasil

VII Centro de Informação Científica e Tecnológica. Fundação Oswaldo Cruz. Rio de Janeiro, RJ, Brasil

Correspondence:

Elisabeth França

Faculdade de Medicina - UFMG

Av. Alfredo Balena, 190/731

30130-100 Belo Horizonte, MG, Brasi

E-mail: efranca@medicina.ufmg.br

Received: 9/23/2013

Approved: 3/17/2014

Article available from: www.scielo.br/rsp

\section{III-defined causes of death in Brazil: a redistribution method based on the investigation of such causes}

\author{
Causas mal definidas de óbito no \\ Brasil: método de redistribuição \\ baseado na investigação do óbito
}

\section{ABSTRACT}

OBJECTIVE: To propose a method of redistributing ill-defined causes of death (IDCD) based on the investigation of such causes.

METHODS: In 2010, an evaluation of the results of investigating the causes of death classified as IDCD in accordance with chapter 18 of the International Classification of Diseases (ICD-10) by the Mortality Information System was performed. The redistribution coefficients were calculated according to the proportional distribution of ill-defined causes reclassified after investigation in any chapter of the ICD-10, except for chapter 18, and used to redistribute the ill-defined causes not investigated and remaining by sex and age. The IDCD redistribution coefficient was compared with two usual methods of redistribution: a) Total redistribution coefficient, based on the proportional distribution of all the defined causes originally notified and b) Non-external redistribution coefficient, similar to the previous, but excluding external causes.

RESULTS: Of the 97,314 deaths by ill-defined causes reported in 2010, 30.3\% were investigated, and $65.5 \%$ of those were reclassified as defined causes after the investigation. Endocrine diseases, mental disorders, and maternal causes had a higher representation among the reclassified ill-defined causes, contrary to infectious diseases, neoplasms, and genitourinary diseases, with higher proportions among the defined causes reported. External causes represented $9.3 \%$ of the ill-defined causes reclassified. The correction of mortality rates by the total redistribution coefficient and non-external redistribution coefficient increased the magnitude of the rates by a relatively similar factor for most causes, contrary to the IDCD redistribution coefficient that corrected the different causes of death with differentiated weights.

CONCLUSIONS: The proportional distribution of causes among the illdefined causes reclassified after investigation was not similar to the original distribution of defined causes. Therefore, the redistribution of the remaining ill-defined causes based on the investigation allows for more appropriate estimates of the mortality risk due to specific causes.

DESCRIPTORS: Cause of Death. Mortality Registries. Underregistration. Vital Statistics. Information Systems. 


\section{RESUMO}

OBJETIVO: Propor método de redistribuição de causas mal definidas de óbito baseado na investigação dessas causas.

MÉTODOS: Foram analisados os resultados das investigações dos óbitos notificados como causas mal definidas (CMD) do capítulo XVIII da Classificação Estatística Internacional de Doenças (CID-10), no Sistema de Informações de Mortalidade em 2010. Os coeficientes de redistribuição foram calculados segundo a distribuição proporcional das causas mal definidas reclassificadas após investigação em qualquer capítulo da CID-10, exceto o capítulo XVIII, e utilizados para redistribuir as causas mal definidas não investigadas e remanescentes, segundo sexo e idade. $O$ coeficiente de redistribuição-CMD foi comparado com dois métodos usuais de redistribuição: a) coeficiente de redistribuição-Total, baseado na distribuição proporcional de todas as causas definidas notificadas; b) coeficiente de redistribuição-Não externas, similar ao anterior, com exclusão das causas externas.

RESULTADOS: Dos 97.314 óbitos por causas mal definidas notificados em 2010, $30,3 \%$ foram investigados. Desses, $65,5 \%$ foram reclassificados em causas definidas após investigação. As doenças endócrinas, transtornos mentais e causas maternas tiveram representação maior entre as causas mal definidas reclassificadas, ao contrário das doenças infecciosas, neoplasias e doenças do aparelho geniturinário, com proporções maiores entre causas definidas notificadas. As causas externas representaram 9,3\% das causas mal definidas reclassificadas. A correção das taxas de mortalidade pelos critérios coeficiente de redistribuição-Total e coeficiente de redistribuição-Não externas aumentou a magnitude das taxas por fator relativamente semelhante para a maioria das causas, ao contrário do coeficiente de redistribuição$\mathrm{CMD}$, que corrigiu as diferentes causas de óbito com pesos diferenciados.

CONCLUSÕES: A distribuição proporcional de causas entre as causas mal definidas reclassificadas após investigação não foi semelhante à distribuição original de causas definidas. Portanto, a redistribuição das causas mal definidas remanescentes com base nas investigações permite estimativas mais adequadas do risco de mortalidade por causas específicas.

DESCRITORES: Causas de Morte. Registros de Mortalidade. SubRegistro. Estatísticas Vitais. Sistemas de Informação.

\section{INTRODUCTION}

Mortality indicators are important for understanding the epidemiological profile of a population; they support both the planning and evaluation of health actions and are, therefore, relevant to analyze the health situation to direct public policies. However, due to problems with information quality, the analysis of trends and main causes in mortality in many low- and middleincome countries is generally restricted to either areas with a higher socioeconomic level or larger cities. In fact, the places with major problems related to the quality of information about deaths have the heaviest disease burden. ${ }^{9}$ Therefore, some methodological proposals for indirect estimates and analyses of corrected data from vital statistics systems have been used in Brazil ${ }^{4,6}$ to include the population groups most at risk from death and disease.

The high proportions of deaths from ill-defined causes in Brazil are worrisome, as they indicate problems related to the access and quality of medical care received by the population, in addition to compromising the reliability of mortality statistics for causes of death. ${ }^{8,10,20}$ These deaths corresponded to $14.3 \%$ of the total in 2000 , with wide variability between cities and even regions: proportions ranged from $28.4 \%$ in the Northeast to $6.3 \%$ in the South. ${ }^{a}$

${ }^{a}$ Ministério da Saúde. Datasus. Brasília (DF); [s.d.] [cited 2013 Jun]. Available from: www.datasus.gov.br 
The ideal method for clarifying a cause listed as illdefined on the death certificate (DC) is investigating records from hospitals and other health services, or interviews with family and health professionals. However, few Brazilian researchers reported field investigations reclassifying causes of death that were listed as illdefined on the death certificate, ${ }^{1,10}$ or cross-checking records to reclassify these causes. ${ }^{20}$

Beginning in 2005, the Ministry of Health initiated a project to upgrade the mortality information with a focus on the country's Northern and Northeastern regions. The main actions were: contracting supporters for the states; developing instruments to investigate deaths, as well as applications to support and monitor municipalities in the process of investigating deaths from ill-defined causes; linking records from the Sistema de Informações de Mortalidade (SIM - Mortality Information System) with other information systems; setting investigation goals; continuous monitoring of investigation results and the "percentage of deaths from ill-defined causes" indicator in each state. ${ }^{\mathrm{b}}$ Since issuing a DC is an integral part of medical care, ${ }^{c}$ a new instruction manual for completing it was widely publicized, ${ }^{\mathrm{d}}$ to raise physicians' awareness of the importance of DC.

The proportion of ill-defined causes of death (IDCD) decreased from $8.6 \%$ to $7.0 \%$ among reported deaths, after including the results of IDCD reclassification in the official statistics published in Brazil in 2010. However, this proportion is relatively high and there are still great differentials between the states and regions. This variation also occurs intra-regionally, with IDCD proportions close to $30.0 \%$ in some states' macro-regions. ${ }^{\mathrm{a}, \mathrm{b}}$ It has thus become important that analyses cause-specific mortality include methods for correcting deaths through the remaining IDCD. The rates' magnitude is affected by these causes, introducing bias into comparisons between places with different proportions of IDCD and in studies of temporal trends.

Redistributing IDCD into defined causes represents a proposal to minimize this problem. Statistical methods for this correction are used based on the behavior of the defined causes that were reported. ${ }^{13}$ More common is the use of proportional redistribution according to the defined causes, registered by sex and age, considering all causes ${ }^{11,12,14,19}$ or only the non-external causes, as proposed in the 1990 Global Burden of Disease Study. ${ }^{16-18, \mathrm{e}}$ However, these redistribution methodologies are not considered satisfactory. ${ }^{10}$ The redistribution methodology based on death distribution of non-external causes is particularly questionable, after findings of violence and accidents among the IDCD investigated. ${ }^{1,10,20}$

The investigation of IDCD represents an important gain in clarifying the cause of death. From this perspective, this study proposes a method for redistributing IDCD based on an investigation of these causes.

\section{METHODS}

Cross-sectional study on the IDCD allocated in chapter 18 (Symptoms, Signs and Abnormal Clinical and Laboratory Findings, Not Elsewhere Classified) of the International Classification of Diseases and HealthRelated Problems, $10^{\text {th }}$ Revision (ICD-10). All deaths registered in the SIM in 2010 were considered.

Investigations of IDCD comprises collecting information about the deceased's terminal illness in health services, such as the basic health units in the Family Health Strategy or health facilities, in the case of hospitalization; as well as collecting information obtained from other sources, such as the Disease Notification Information System, Hospital Information System, Serviço de Verificação de Óbito (SVO - Death Verification Service), and Instituto Médico Legal (IML - Forensic Institute). In cases where the information obtained from the health services prohibits the cause of death to be identified, an investigation should be conducted through a home interview by a health professional; data should be collected on a standardized verbal autopsy form, which seeks to obtain information about the signs and symptoms presented by the patient in the period prior to death and were observed by family members who lived with the deceased during this period. Analyzing all the information present on the form, an accredited physician should determine the sequence of causes that led to the death, as well as its underlying

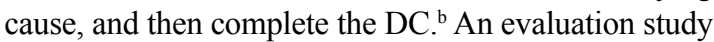
of the process of investigating IDCD in Alagoas in 2010 indicates that the professionals responsible for conducting the interviews are mostly nurses; the presence of the physician responsible for certifying the underlying cause after investigation was listed on the forms in approximately $1 / 3$ of the verbal autopsies conducted. A physician defined the underlying cause of death in 12 out of the 18 randomly selected municipalities; in four cities, this task was the responsibility of a multidisciplinary technical team that included the participation of physicians. ${ }^{3}$

The DC that originally showed IDCD were categorized into: (i) IDCD investigated and reclassified (cause clarified/changed after investigation): certificates that ended up having a defined underlying cause of death,

\footnotetext{
b Ministério da Saúde. Manual para investigação do óbito com causa mal definida. Brasília (DF): 2009. (Série A. Normas e Manuais Técnicos). ${ }^{c}$ Conselho Federal de Medicina. Resolução 1779. Diario Oficial Uniao. 5 Dez 2005;Seção1:121.

d Ministério da Saúde. Secretaria de Vigilância em Saúde. Departamento de Análise de Situação de Saúde. Manual de Instruções para o preenchimento da Declaração de Óbito. Brasília (DF); 2011.

e Murray CJL, Lopez AD. Estimating causes of death: new methods and global and regional applications for 1990. Boston: Harvard School of Public Health; 1996. The global burden of disease. p. 118-200.
} 
i.e., belonging to any chapter of ICD-10 except chapter 18; the new causes were arranged in the respective classes, in this case, the chapters and groups of ICD-10; (ii) IDCD not reclassified (an investigation of the IDCD was not performed or the cause was not clarified/changed after investigation): certificates that continued to be included in chapter 18 of ICD-10. This category also encompasses deaths from causes not originally classified under any chapter of ICD-10 or from chapters of defined causes (usually deaths of women of childbearing age or children) that were moved to chapter 18 after investigation. The total comprises the group that is, here, called remaining IDCD.

Investigated IDCD are reported in a specific field in the SIM application. The underlying causes presented by the system, called final causes, include the investigated and reclassified cases (when the IDCD is replaced by an underlying cause not belonging to chapter 18 of ICD-10 in the SIM). The cause of death (COD) before investigation is called the original COD. The CODs of the DC originally classified as IDCD were analyzed by crosschecking the classifications of the original COD with the final ones.

The proposed method includes redistributing the remaining IDCD according to the reclassification obtained in the first group. The assumption is that the profile of causes among the remaining IDCD will be similar to those of the reclassified IDCD. The redistribution should be performed according to the proportional distribution of causes observed among the investigated and reclassified IDCDs, i.e., according to the redistribution coefficient RC-IDCD, which provides a redistribution factor of the remaining IDCDs for the ICD-10 chapters that concern defined causes. This redistribution was performed according to the following steps:

1. Calculation of the RC-IDCD based on the IDCD reclassified for each chapter of the ICD-10, by age and sex;

2. The RC-IDCD obtained were applied to the non-reclassified IDCD, and redistributed into the chapters of defined causes;

3. The total number of deaths corrected with a defined cause was calculated by the sum of the deaths registered in the chapter with a defined cause after including the deaths reclassified in IDCD investigation plus the deaths redistributed in the prior step. As an example, the number of deaths corrected by the RC-IDCD for neoplasms (Corrected Deaths RC-IDCD ${ }_{\text {neo }}$ ) was estimated, by age and sex:

Corrected Deaths RC-IDCD neo $_{\text {e }}$ original deaths from neoplasm + IDCD reclassified as neoplasm + IDCD* RC - IDCD for neoplasm; in which RC-IDCD ${ }_{\text {neo }}=$ number of IDCD investigated and reclassified as neoplasm/total number of investigated and reclassified IDCD.
The method of using the RC-IDCD was compared with two other commonly used redistribution methods: a) according to the distribution of all defined causes (IDCD redistributed according to the proportional distribution of the originally defined causes by sex and age - redistribution coefficient called RC-Total); b) according to the distribution of the non-external defined causes (IDCD redistributed according to the proportional distribution of the originally defined causes by sex and age, excluding external causes - redistribution coefficient RC-Non-external).

The corrections were made according to sex and quinquennial age group. The data with unknown sex and age were redistributed proportionally among the data with known sex and age. Mortality rates for uncorrected selected causes were calculated from the number of deaths reported in the SIM in 2010; those with correction were calculated from the number of deaths corrected by the RC-IDCD and other redistribution coefficients evaluated. The population considered was the 2010 Brazilian Census.

\section{RESULTS}

In $2010,8.6 \%$ of $1,136,947$ deaths that were reported to the SIM were originally classified as IDCD. Investigations of these causes occurred in all regions of the country, particularly in the Midwest and Northeast, which also had proportionately more cases of IDCD reclassified. The proportions of the remaining IDCD were different among the regions (from $11.8 \%$ in the North to $4.0 \%$ in the Midwest) (Table 1).

About $20.0 \%$ of IDCD were reclassified in all age groups and both sexes, with a small increase among women of childbearing age and smaller proportions in the extreme age groups (Table 2).

Among those reported, 1,037,967 deaths resulted from defined causes and 97,314 were from IDCD. After investigating these causes, $19.8 \%$ of the deaths were reclassified as defined causes of death. These were added to the other defined causes, totaling 1,057,325 deaths from defined causes in the SIM database. In addition to the 78,011 IDCD that were not reclassified $(67,827$ were originally IDCD and were not investigated and 10,183 were investigated and not reclassified), 1,611 more deaths were added to the IDCD group for two main reasons: 1) deaths originally not classified in any chapter of the ICD-10;2) deaths from other chapters and not in chapter 18 of ICD-10, and which changed to IDCD after investigation. Therefore, 79,622 deaths continued to be IDCD, to be subsequently redistributed (Figure).

The proportions of defined causes among the IDCD that were reclassified and represented by RC-IDCD were different from the proportions among the reported deaths, with a higher proportion of endocrine diseases, 
Table 1. Number and proportion of deaths from ill-defined causes after investigation. Brazil and regions, 2010.

\begin{tabular}{lcccccc}
\hline Variable & North & Northeast & Southeast & South & Midwest & Brazil \\
\hline Deaths originally reported as IDCD & 8,813 & 30,527 & 43,524 & 10,178 & 4,272 & 97,314 \\
Proportion of deaths originally reported as & 13.5 & 10.7 & 8.1 & 5.7 & 5.9 & 8.6 \\
IDCD $(\%)^{\mathrm{a}}$ & & & & & & \\
Proportion of investigated IDCD (\%) & 22.4 & 37.6 & 26.2 & 27.4 & 43.0 & 30.3 \\
Reclassified IDCD & 1,156 & 8,566 & 6,538 & 1,610 & 1,433 & 19,303 \\
Proportion of reclassified IDCD (\%) $)^{\mathrm{b}}$ & 13.1 & 28.1 & 15.0 & 15.8 & 33.5 & 19.8 \\
Remaining IDCD after including those & 7,657 & 21,961 & 36,986 & 8,568 & 2,839 & 78,011 \\
reclassified & & & & & & \\
IDCD from other investigations & 75 & 235 & 1,061 & 175 & 65 & 1,611 \\
Remaining IDCD (n) & 7,732 & 22,196 & 38,047 & 8,743 & 2,904 & 79,622 \\
Proportion of remaining IDCD (\%) & 11.8 & 7.8 & 7.1 & 4.9 & 4.0 & 7.0 \\
Total deaths & 65,425 & 284,635 & 534,495 & 179,428 & 72,964 & $1,136,947$ \\
\hline
\end{tabular}

IDCD: ill-defined causes of death

a $(\%)$ calculated relative to the total number of reported deaths.

b $(\%)$ calculated relative to the deaths reported as being from ill-defined causes.

Table 2. Number and proportion of deaths from ill-defined causes reclassified according to age and sex. Brazil, 2010.

\begin{tabular}{|c|c|c|c|c|c|c|c|c|c|}
\hline \multirow{3}{*}{$\begin{array}{l}\text { Sex/Age } \\
\text { group (years) }\end{array}$} & \multicolumn{3}{|c|}{ Male } & \multicolumn{3}{|c|}{ Female } & \multicolumn{3}{|c|}{ Total } \\
\hline & \multirow{2}{*}{$\begin{array}{c}\text { IDCD-total } \\
\mathrm{n}\end{array}$} & \multicolumn{2}{|c|}{ IDCD-reclassified } & \multirow{2}{*}{$\begin{array}{c}\text { IDCD-total } \\
\mathrm{n}\end{array}$} & \multicolumn{2}{|c|}{ IDCD-reclassified } & \multirow{2}{*}{$\begin{array}{c}\text { IDCD-total } \\
\mathrm{n}\end{array}$} & \multicolumn{2}{|c|}{ IDCD-reclassified } \\
\hline & & $\mathrm{n}$ & $\%$ & & $\mathrm{n}$ & $\%$ & & $\mathrm{n}$ & $\%$ \\
\hline$<1$ & 1,028 & 191 & 18.5 & 713 & 127 & 17.8 & 1,741 & 317 & 18.2 \\
\hline 1 to 4 & 369 & 74 & 20.1 & 291 & 52 & 17.9 & 660 & 126 & 19.2 \\
\hline 5 to 9 & 181 & 42 & 23.3 & 139 & 28 & 20.1 & 320 & 70 & 21.9 \\
\hline 10 to 14 & 235 & 47 & 20.1 & 198 & 45 & 22.8 & 432 & 92 & 21.4 \\
\hline 15 to 19 & 667 & 132 & 19.7 & 344 & 109 & 31.7 & 1,011 & 241 & 23.8 \\
\hline 20 to 24 & 954 & 196 & 20.5 & 397 & 125 & 31.5 & 1,350 & 321 & 23.8 \\
\hline 25 to 29 & 1,191 & 268 & 22.5 & 500 & 143 & 28.6 & 1,691 & 411 & 24.3 \\
\hline 30 to 34 & 1,610 & 309 & 19.2 & 679 & 196 & 28.9 & 2,290 & 506 & 22.1 \\
\hline 35 to 39 & 1,960 & 403 & 20.6 & 804 & 222 & 27.6 & 2,763 & 625 & 22.6 \\
\hline 40 to 44 & 2,657 & 547 & 20.6 & 1,122 & 300 & 26.8 & 3,779 & 847 & 22.4 \\
\hline 45 to 49 & 3,394 & 693 & 20.4 & 1,528 & 395 & 25.9 & 4,922 & 1,089 & 22.1 \\
\hline 50 to 54 & 4,040 & 755 & 18.7 & 1,755 & 380 & 21.7 & 5,795 & 1,136 & 19.6 \\
\hline 55 to 59 & 4,139 & 864 & 20.9 & 1,933 & 377 & 19.5 & 6,072 & 1,241 & 20.4 \\
\hline 60 to 64 & 4,505 & 919 & 20.4 & 2,404 & 548 & 22.8 & 6,909 & 1,467 & 21.2 \\
\hline 65 to 69 & 4,583 & 897 & 19.6 & 2,845 & 583 & 20.5 & 7,428 & 1,480 & 19.9 \\
\hline 70 to 74 & 5,147 & 1,003 & 19.5 & 3,790 & 772 & 20.4 & 8,937 & 1,775 & 19.9 \\
\hline 75 to 79 & 5,184 & 1,073 & 20.7 & 4,283 & 837 & 19.5 & 9,467 & 1,910 & 20.2 \\
\hline 80 to 84 & 5,120 & 967 & 18.9 & 5,346 & 1,008 & 18.8 & 10,466 & 1,975 & 18.9 \\
\hline $85+$ & 8,555 & 1,542 & 18.0 & 12,724 & 2,132 & 16.8 & 21,279 & 3,673 & 17.3 \\
\hline Total & 55,518 & 10,923 & 19.7 & 41,796 & 8,380 & 20.1 & 97,314 & 19,303 & 19.8 \\
\hline
\end{tabular}

IDCD: ill-defined causes of death

${ }^{a}$ Unknown age and sex were redistributed.

mental disorders, nervous system diseases, circulatory diseases and maternal causes among the IDCD. Infectious diseases, neoplasms, respiratory diseases, genitourinary diseases, perinatal disorders and congenital malformations occurred in a relatively smaller proportion (Table 3). Neoplasms showed different proportions in different parts of the country (higher in the North and Northeast and lower in the South, Southeast, and Midwest) (data not presented). There was a relatively significant proportion of external causes among 


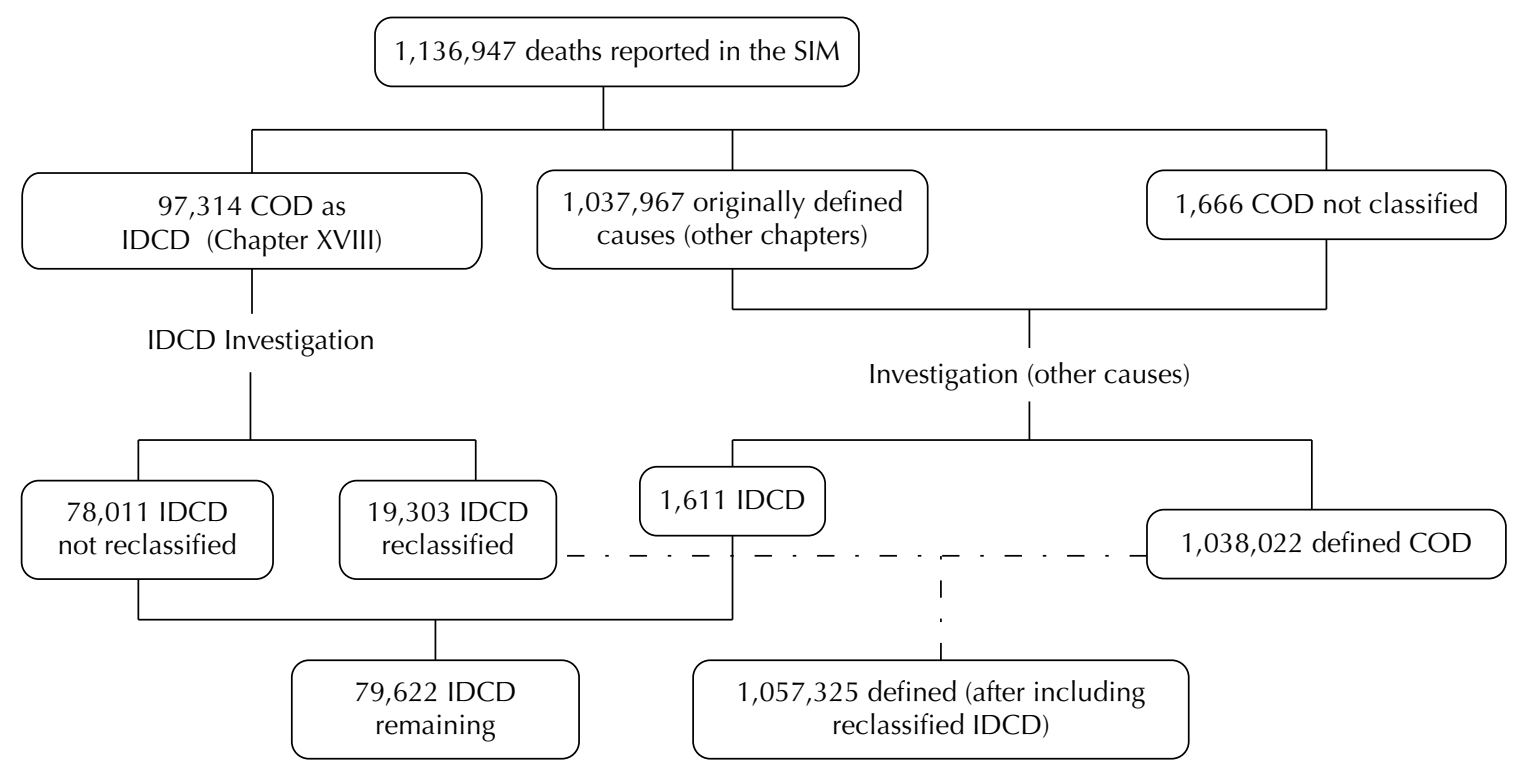

SIM: Mortality Information System; COD: cause of death; IDCD: ill-defined causes of death

Figure. Flowchart of investigations conducted for ill-defined causes of death. Brazil, 2010.

the IDCD (9.3\% of the IDCDs reclassified for Brazil), higher in men $(10.5 \%)$. While, the proportion of endocrine diseases among the IDCD was higher in women $(13.1 \%)$, the proportion of mental and behavioral disorders was higher in men $(8.7 \%$ ) (data not presented). There was an increase in the number of deaths for all the chapters of defined causes according to the three criteria considered, without implying changes in the rank of leading causes of death (Table 3 ).

With the exception of perinatal diseases, congenital malformations, and external causes, there was a similar percentage increase for risk of death for almost all causes when using RC-Total and RC-Non-external, unlike the proposed new criterion based on RC-IDCD, which corrected the different causes of death with different weights. By this criterion, endocrine diseases, particularly diabetes, diseases of the circulatory system and, particularly, maternal causes and mental disorders, had greater representation than they did using the other two criteria. In contrast, neoplasms, infectious diseases, and genitourinary diseases showed smaller relative increases. External causes were not addressed in the redistribution process using RC-Non-external and only had a small increase among the redistributed causes due to correction for unknown age and sex. RC-IDCD considered a relatively smaller weight for them among the IDCD when compared to RC-Total (Table 4).

\section{DISCUSSION}

This study indicates that the proportional distribution of causes among the IDCD reclassified after investigation differed from the original distribution of defined causes.
Therefore, we consider that the method proposed here for redistributing IDCD based on the results of investigations conducted by the health services enables more reliable estimates of mortality risk for specific causes, when compared to the usual redistribution methods.

Pro rata distribution is the most commonly used method for redistributing IDCD. The redistribution coefficient is calculated based on the distribution of underlying causes of death by sex and age group, considering all defined causes ${ }^{11,12,14,19}$ or only non-external causes. ${ }^{16-18}$ On the other hand, redistribution based on empirical studies is less used in Brazil, having been reported for specific causes such as cancer as well as maternal and external causes. ${ }^{4,6,17}$

Some authors propose statistical methods for correcting information, such as Cavalini et $\mathrm{al}^{2}$ (2007), which used the Bayesian estimators of James-Stein to correct underreporting and redistribute IDCD for deaths and hospitalizations; they observed an increase in the number of deaths and a modification in the structure of proportional mortality in the North and Northeast. Paes \& Gouveia ${ }^{13}$ (2010) employed the Lederman method to redistribute IDCD to non-external causes, with greater gains for circulatory diseases and smaller gains for infectious and parasitic diseases.

Few published Brazilian studies exists on clarifying IDCD. Mello Jorge et al ${ }^{10}$ investigated 294 IDCD in hospitals, Forensic Institutes (IML), and households in 13 municipalities in the states of Sergipe, Sao Paulo, and Mato Grosso, in 2000. Of these, $61.9 \%$ were reclassified into defined causes after investigation. Campos 


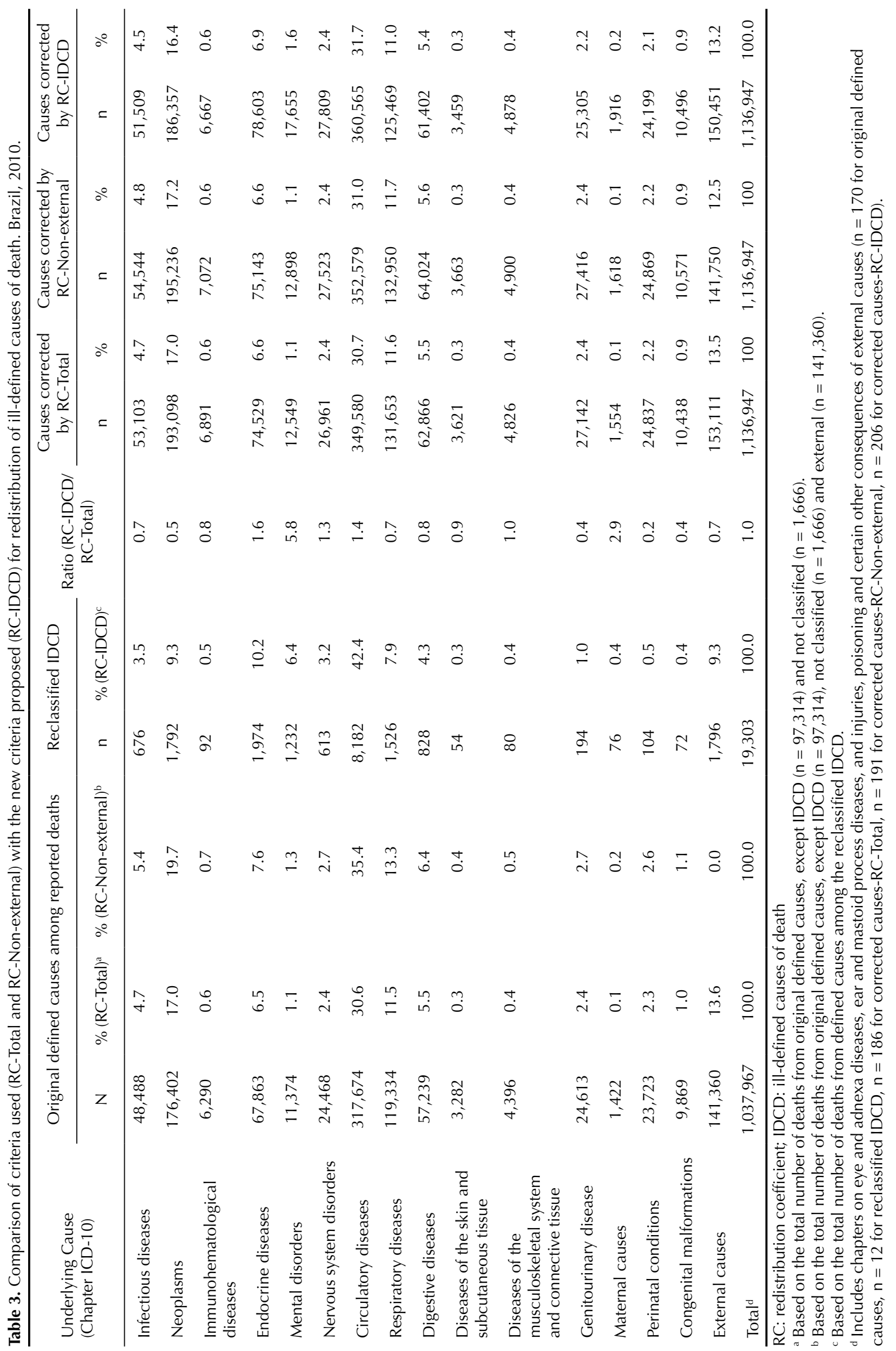


et $\mathrm{al}^{1}$ (2010) investigated 202 IDCD in households, using the verbal autopsy method, in health services and IML, in a sample of 10 municipalities in the macro-region of Minas Gerais, Southeastern Brazil, in 2007; the COD was reclassified in $63.9 \%$ of the cases. Teixeira et $\mathrm{al}^{20}$ (2006) sought to clarify IDCD in Rio de Janeiro, Southeastern Brazil, in 1998 by relating data from the SIM and Hospital Information System. Of the 12,633 IDCD, 16.3\% were reclassified, which diminished the importance of IDCD in proportional mortality by causes. Similar findings were observed in this study: $65.5 \%$ of IDCD investigated in the country had their cause reclassified after investigation (19.8\% of IDCD reported in 2010).

The project to qualify the Brazilian Mortality Information System has enabled the clarification of IDCD, with a sig-

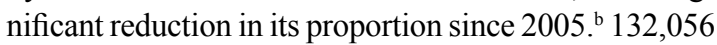
IDCD between 2006 and 2010 were investigated in the country, and $64.2 \%$ of IDCD investigated were reclassified into a defined group of causes of death and included in the official statistics available on the Internet. The profile of causes of death among the reclassified IDCD differs from those observed among the defined causes that were reported, ${ }^{5}$ confirming previous findings ${ }^{10}$ and those of this study.

Despite the importance of correction for IDCD, there is no standardization in the redistribution methods or terminology used, which hinders its routine use in mortality statistics. The very definition of grouping IDCD is not consensual. Various codes considered incomplete or "garbage codes" from chapters other than chapter 18 of ICD-10 have been added to the IDCD group, since they do not characterize the cause of death. ${ }^{9}$ The present study only considered IDCD with codes from chapter 18, which have more recognized redistribution methodologies.

Various terms are used for IDCD with a defined COD after investigation, such as reallocated, recovered, clarified, altered or reclassified IDCD. ${ }^{1,10,20}$ We opted to use the term reclassified IDCD, which was considered more appropriate for this analysis since the allocation of the

Table 4. Cause-specific mortality rates corrected ${ }^{\mathrm{a}}$ according to different redistribution criteria for ill-defined causes of death. Brazil, 2010.

\begin{tabular}{|c|c|c|c|c|c|c|c|}
\hline \multirow{3}{*}{$\begin{array}{l}\text { Underlying Cause } \\
\text { (ICD-10 Chapter) }\end{array}$} & \multirow{3}{*}{$\begin{array}{c}\text { Rate } \\
\text { with no } \\
\text { correction } \\
\text { (a) }\end{array}$} & \multicolumn{2}{|c|}{$\begin{array}{l}\text { Corrected rate } \\
(\text { RC-Total })^{c}\end{array}$} & \multicolumn{2}{|c|}{$\begin{array}{c}\text { Corrected rate } \\
(\text { RC-Non-external })^{\mathrm{c}}\end{array}$} & \multicolumn{2}{|c|}{$\begin{array}{l}\text { Corrected rate } \\
(\text { RC-IDCD })^{c}\end{array}$} \\
\hline & & Rate $^{b}$ & Increase $(\%)$ & Rate $^{b}$ & Increase (\%) & Rate $^{b}$ & Increase (\%) \\
\hline & & (b) & (b/a) & (c) & (c/a) & (d) & $(d / a)$ \\
\hline Infectious diseases & 25.42 & 27.84 & 9.5 & 28.59 & 12.5 & 27.00 & 6.2 \\
\hline Neoplasms & 92.48 & 101.23 & 9.5 & 102.35 & 10.7 & 97.69 & 5.6 \\
\hline Immunohematological diseases & 3.30 & 3.61 & 9.5 & 3.71 & 12.4 & 3.50 & 6.0 \\
\hline Endocrine diseases & 35.58 & 39.07 & 9.8 & 39.39 & 10.7 & 41.21 & 15.8 \\
\hline Mental disorders & 5.96 & 6.58 & 10.3 & 6.76 & 13.4 & 9.26 & 55.2 \\
\hline Nervous system disorders & 12.83 & 14.13 & 10.2 & 14.43 & 12.5 & 14.58 & 13.7 \\
\hline Circulatory diseases & 166.53 & 183.26 & 10.0 & 184.83 & 11.0 & 189.02 & 13.5 \\
\hline Respiratory diseases & 62.56 & 69.02 & 10.3 & 69.70 & 11.4 & 65.77 & 5.1 \\
\hline Digestive diseases & 30.01 & 32.96 & 9.8 & 33.56 & 11.9 & 32.19 & 7.3 \\
\hline $\begin{array}{l}\text { Diseases of the skin and } \\
\text { subcutaneous tissue }\end{array}$ & 1.72 & 1.90 & 10.3 & 1.92 & 11.6 & 1.81 & 5.4 \\
\hline $\begin{array}{l}\text { Diseases of the } \\
\text { musculoskeletal system and } \\
\text { connective tissue }\end{array}$ & 2.30 & 2.53 & 9.8 & 2.57 & 11.5 & 2.56 & 11.0 \\
\hline Genitourinary disease & 12.90 & 14.23 & 10.3 & 14.37 & 11.4 & 13.27 & 2.8 \\
\hline Maternal causes & 0.75 & 0.81 & 9.3 & 0.85 & 13.8 & 1.00 & 34.8 \\
\hline Perinatal conditions & 12.44 & 13.02 & 4.7 & 13.04 & 4.8 & 12.69 & 2.0 \\
\hline Congenital malformations & 5.17 & 5.47 & 5.8 & 5.54 & 7.1 & 5.50 & 6.4 \\
\hline External causes & 74.11 & 80.27 & 8.3 & 74.31 & 0.3 & 78.87 & 6.4 \\
\hline
\end{tabular}

\footnotetext{
${ }^{a}$ In calculating the rates, the correction of death underreporting was not considered (completeness of total deaths estimated at $\left.94.2 \%\right)$.

b Per 100,000 inhabitants.

c Ill-defined causes redistributed according to sex and age, with redistribution of unknown sex and age.
} 
new COD was performed using an existing classification, the ICD-10. The term redistributed IDCD refers to the certificates that underwent processing after redistribution among the defined causes of death.

When comparing the IDCD redistribution method used in this study with the usual methods, a greater relative proportion of endocrine diseases, mental disorders, and maternal causes exists. This suggests a possible underestimation of these causes when using the usual redistribution methods. Results similar to those of this study were observed in 13 Brazilian municipalities in $2000,{ }^{10}$ which also found a higher incidence of deaths from mental disorders among the investigated IDCD $(6.6 \%)$ than among the reported deaths $(1.1 \%)$. The same occurred for maternal causes $(0.8 \%$ of IDCD) and endocrine diseases, mainly diabetes. However, a study in Thailand ${ }^{15}$ found that verbal autopsy may overestimate the importance of diabetes post-investigation.

The increase in the number of deaths due to maternal causes when using RC-IDCD is likely related to the investigations conducted by maternal death prevention committees, active in most municipalities. On the other hand, proportional mortality by neoplasms decreased with the use of correction based on this coefficient, possibly due to a better certification of these causes than the others among IDCD. ${ }^{6,10}$ The finding is consistent with the different proportions among the regions, higher in the North and Northeast and lower in the South, Southeast, and Midwest, where the coverage of deaths and access to diagnosis are probably better.

External causes are considered to be well recorded and, therefore, would not be part of the IDCD group..$^{13,17,18}$ However, there was a relatively significant proportion of these causes among IDCD (9.3\% of the reclassified IDCD for Brazil in 2010), probably related to the active search for clarifying IDCD that was conducted in the IML in various municipalities. Studies in Brazilian municipalities also showed significant proportions of external causes among IDCD. ${ }^{1,10,20}$ Khosravi et $\mathrm{al}^{7}$ (2008) observed that $9.6 \%$ of IDCD in adults referred to external causes in Iran.

The redistribution of deaths from ill-defined causes may result in overestimating or underestimating specific mortality rates by causes. However, while the quality of information is "questionable", it will be necessary to provide more reliable estimates of mortality rates by age and sex. As information quality improves, the contribution of this correction will diminish. Therefore, it is necessary to decrease the proportion of IDCD cases that need to be reclassified and redistributed, which can be achieved with better care and better completion of DC by physicians.

This study did not seek to define a cutoff point for the proportion of IDCD to which the redistribution method should be applied, which would require another type of design. In general, it is considered that the proportion of IDCD from chapter 18 of ICD-10, together with other selected, poorly designed codes (I46.1, I46.9, I95.9, I99, J96.0, J96.9, P28.0, C76, C80, C97, Y10Y34, and Y87.2), should not exceed 5.0\% for deaths of non-elderly individuals ( $<65$ years) ${ }^{\mathrm{f}}$ which was not achieved in either Brazil or its regions in 2010.

This study, by proposing the use of empirical data to redistribute IDCD, allows more suitable estimates for risk of cause-specific mortality, and values and encourages the health services' enormous effort to investigate deaths with an undefined underlying cause. Strategies to improve information quality should be encouraged, including the role of physicians and their participation in the appropriate completion of DC.

\footnotetext{
${ }^{\mathrm{f}}$ AbouZahr C, Mikkelsen L, Rampatige R, Lopez A. Mortality statistics: a tool to enhance understanding and improve quality. Brisbane: Health Information Systems Knowledge Hub; 2010 [cited 2014 Feb]. (Working Paper Series, 13). Available from: http://www.uq.edu.au/hishub/docs/ WP13/HISHUB-WP13-KP-05-WEB-9Mar12.pdf
} 


\section{REFERENCES}

1. Campos D, França E, Loschi RH, Souza MFM. Uso da autópsia verbal na investigação de óbitos com causa mal definida em Minas Gerais Brasil. Cad Saude Publica. 2010;26(6):1221-33. DOI:10.1590/S0102-311X2010000600015

2. Cavalini LT, Ponce de Leon ACM. Correção de sub-registros de óbitos e proporção de internações por causas mal definidas. Rev Saude Publica. 2007;41(1):85-93. DOI:10.1590/S0034-89102007000100012

3. França EB, Cunha CC, Vasconcelos AMN, Escalante JJC, Abreu DMX, Lima RB, et al. Avaliação da implantação do programa "Redução do percentual de óbitos por causas mal definidas" em um estado do Nordeste do Brasil. Rev Bras Epidemiol. 2014;17(1):119-134. DOI: 10.1590/1415-790X201400010010.

4. França E, Rao C, Abreu DMX, Souza MFM, Lopez AD. Comparison of crude and adjusted mortality rates from leading causes of death in northeastern Brazil. Rev Panam Salud Publica. 2012;31(4):275-82. DOI:10.1590/S1020-49892012000400002

5. França EB, Souza FM, Ishitani LH, Teixeira R, Szwarcwald CL. Strengthening vital statistics in Brazil: investigation of ill-defined causes of death and implications on mortality statistics. Lancet. 2013;381(Suppl2):17-9. DOI:10.1016/S0140-6736(13)61305-7

6. Gamarra CJ, Valente JG, Silva GA. Correção da magnitude da mortalidade por câncer do colo do útero no Brasil, 1996-2005. Rev Saude Publica. 2010;44(4):629-38. DOI:10.1590/S0034-89102010000400006

7. Khosravi A, Rao C, Naghavi M, Taylor R, Jafaria $\mathrm{N}$, Lopez AD. Impact of misclassification on measures of cardiovascular disease mortality in the Islamic Republic of Iran: a cross-sectional study. Bull World Health Organ. 2008;86(9):688-96. DOI:10.2471/BLT.07.046532

8. Laurenti R, Mello Jorge MHP, Gotlieb SL. A confiabilidade dos dados de mortalidade e morbidade por doenças crônicas não-transmissíveis. Cienc Saude Coletiva. 2004;9(4):909-21. DOI:10.1590/S1413-81232004000400012

9. Mathers CD, Fat DM, Inoue M, Rao C, Lopez AD. Counting the dead and what they died from: an assessment of the global status of cause of death data. Bull World Health Organ. 2005;83(3):171-7. DOI:10.1590/S0042-96862005000300009

10. Mello Jorge MHP, Gotlieb SLD, Laurenti R. O sistema de informações sobre mortalidade: problemas e propostas para o seu enfrentamento I - Mortes por causas naturais. Rev Bras Epidemiol. 2002;5(2):197-223. DOI:10.1590/S1415-790X2002000200008
11. Oliveira GMM, Klein $\mathrm{CH}$, Silva NAS. Mortalidade por doenças cardiovasculares em três estados do Brasil de 1980 a 2002. Rev Panam Salud Publica. 2006;19(2):85-93. DOI:10.1590/S1020-49892006000200003

12. Oliveira GMM, Silva NAS, Klein $\mathrm{CH}$. Mortalidade Compensada por Doenças Cardiovasculares no Período de 1980 a 1999 - Brasil. Arq Bras Cardiol. 2005;85(5):305-13. DOI:10.1590/S0066-782X2005001800002

13. Paes NA, Gouveia JF. Recuperação das principais causas de morte do Nordeste do Brasil: impacto na expectativa de vida. Rev Saude Publica. 2010;44(2):301-9. DOI:10.1590/S0034-89102010000200010

14. Périssé G, Medronho RA, Escosteguy CC. Espaço Urbano e a Mortalidade por Doença Isquêmica do Coração em Idosos no Rio de Janeiro. Arq Bras Cardiol. 2010;94(4):463-71. DOI:10.1590/S0066-782X2010005000009

15. Polprasert W, Rao C, Adair T, Pattaraarchachai J, Porapakkham Y, Lopez AD. Cause-of-death ascertainment for deaths that occur outside hospitals in Thailand: application of verbal autopsy methods. Popul Health Metr. 2010;8(1):13. DOI:10.1186/1478-7954-8-13

16. Porapakkham Y, Rao C, Pattaraarchachai J, Polprasert W, Vos T, Adair T, et al. Estimated causes of death in Thailand, 2005: implications for health policy. Popul Health Metr. 2010;8(1):14. DOI:10.1186/1478-7954-8-14

17. Silva GA, Gamarra CJ, Girianelli VR, Valente JG. Tendência da mortalidade por câncer nas capitais e interior do Brasil entre 1980 e 2006. Rev Saude Publica. 2011;45(6):1009-18. DOI:10.1590/S0034-89102011005000076

18. Soares DA, Gonçalves MJ. Mortalidade cardiovascular e impacto de técnicas corretivas de subnotificações e óbitos mal definidos. Rev Panam Salud Publica. 2012;32(3):199-206. DOI:10.1590/S1020-49892012000900005

19. 19. Soares GP, Brum JD, Oliveira GMM, Klein $\mathrm{CH}$, Silva NAS. Mortalidade por todas as causas e por doenças cardiovasculares em três estados do Brasil, 1980 a 2006. Rev Panam Salud Publica. 2010;28(4):258-66. DOI:10.1590/S1020-49892010001000004

20. Teixeira CLS, Klein CH, Bloch KV, Coeli CM. Reclassificação dos grupos de causas prováveis dos óbitos de causa mal definida, com base nas Autorizações de Internação Hospitalar no Sistema Único de Saúde, Estado do Rio de Janeiro, Brasil. Cad Saude Publica. 2006;22(6):1315-24. DOI:10.1590/S0102-311X2006000600020 


\section{HIGHLIGHTS}

This study proposes a methodology for redistributing ill-defined causes of death (IDCD), based on empirical data from investigations conducted in 2010, in health services and households, using standardized verbal autopsy forms.

The redistribution of IDCD using the proposed methodology not only improves the quality of mortality statistics in Brazil but also increases the potential for using mortality indicators to make decisions based on evidence.

The distribution of reclassified IDCD differs from that observed among deaths with defined causes, with a higher proportion of endocrine diseases, mental disorders, nervous system diseases, circulatory diseases, and maternal causes among the IDCD.

The results of this research can be incorporated by the managers of the Mortality Information System and by Health Surveillance professionals, in the three spheres of government, to redistribute IDCD and produce epidemiological indicators with corrected mortality rates in the states and, therefore, with more appropriate estimates for mortality risk by specific causes.

Professor Rita de Cássia Barradas Barata Scientific Editor 